\title{
Headache and wine. Are all wines the same?
}

\author{
S Diaz-Insa ${ }^{1 *}$, A Rodrigo $^{1}$, YM Pamblanco ${ }^{2}$, L Lacruz $^{2}$, A Soler $^{2}$, C Guillen $^{2}$ \\ From The European Headache and Migraine Trust International Congress \\ London, UK. 20-23 September 2012
}

\section{Objectives}

Classically, most migraineurs refer some relationship between drinking wine and headache. There are few previous studies confirming this. Our aim is to confirm (or not) this relationship and find out if all kind of wines have the same effect producing headache.

\section{Methods}

Based in previous data we have designed a simple and structured questionnaire. All patients attending a headache clinic (one day/week) during 6 months have been required to fill it. Age, gender, headache type (IHC-2004 criteria) are recorded. Questions referring to usual intake of wine, wine producing headache, kind of wine (red/white/sweet/ cava-champagne) were asked. Questions about other alcoholic beverages producing headache and hangover headache also were presented. In this paper we describe the Results.

\section{Results}

397 patients filled the questionnaire. Mean age 44.4 years, $79.6 \%$ females. Mean headache days, 11.5 per month. Migraine was the commonest headache type (74.8\%). Just 9.1\% drink wine usually. 166 patients (41.8\%) affirm drinking wine produces headache. Some interesting differences were found between headache types and migraine subtypes: $55.6 \%$ of chronic migraine vs just 19\% of MAura patients. Patients referring headache due to wine conssumption (most with little quantity) appoints red wine in $60 \%$, cavachampagne $47 \%$, white $36 \%$ and sweet $32 \%$. Most of them have stopped drinking wine due to this headache-producing problem. Other alcoholic beverages (mostly high-alcoholdegree) induces headache in $26.7 \%, 4 / 5$ of them having also wine-induced headache. Hangover headache was recognised by half of the patients along their lifetime, but just $30 \%$ of them referred this headache to be similar to their usual headache.

Headache-Neurology Unit, Spain

Full list of author information is available at the end of the article

\section{Conclusions}

Headache due to wine conssumption seems to be frequent, at least in migraine patients. Not all kinds of wine are referred as headache inducers, there's some special sensitivity to different wine types in different patients. Hangover headache feels different to usual headache by the majority.

\section{Author details}

${ }^{1}$ Headache-Neurology Unit, Spain. ${ }^{2}$ Neurology Unit, Spain.

Published: 21 February 2013

Reference

1. Panconesi J.. Headache Pain 2008, Nicolodi \& Sicuteri, Drugs Exp Clin Res, 1999 Littlewood et al, Lancet, 1988 Peatfield, Headache, 1995.

doi:10.1186/1129-2377-14-S1-P32

Cite this article as: Diaz-Insa et al:: Headache and wine. Are all wines the same? The Journal of Headache and Pain 2013 14(Suppl 1):P32.

\section{SpringerOpen ${ }^{\odot}$}

(C) 2013 Diaz-Insa et al; licensee Springer. This is an Open Access article distributed under the terms of the Creative Commons Attribution License (http://creativecommons.org/licenses/by/2.0), which permits unrestricted use, distribution, and reproduction in any medium, provided the original work is properly cited.
Submit your manuscript to a SpringerOpen ${ }^{\circ}$ journal and benefit from:

- Convenient online submission

- Rigorous peer review

- Immediate publication on acceptance

- Open access: articles freely available online

- High visibility within the field

- Retaining the copyright to your article

Submit your next manuscript at $>$ springeropen.com 